\title{
Glial Cell Line-Derived Neurotrophic Factor Administration in Postnatal Life Results in Motor Unit Enlargement and Continuous Synaptic Remodeling at the Neuromuscular Junction
}

\author{
Cynthia R. Keller-Peck, ${ }^{1}$ Guoping Feng, ${ }^{1}$ Joshua R. Sanes, ${ }^{1}$ Qiao Yan, ${ }^{3}$ Jeff W. Lichtman, ${ }^{1}$ and \\ William D. Snider² \\ ${ }^{1}$ Department of Anatomy and Neurobiology, Washington University School of Medicine, St. Louis, Missouri 63110, \\ 2Neuroscience Center, University of North Carolina School of Medicine, Chapel Hill, North Carolina 27599, and \\ 3Neurobiology, Amgen, Inc., Thousand Oaks, California 91320
}

Overexpression of glial cell line-derived neurotrophic factor (GDNF) in embryonic muscle fibers causes dramatic hyperinnervation of neuromuscular junctions. However, it is not known whether GDNF induces the extra innervation by regulation of axonal branching and/or synaptic maintenance. To address this issue, high levels of circulating GDNF were established by administering subcutaneous injections starting either at birth or later and continuing for up to $40 \mathrm{~d}$. Treatment with exogenous GDNF beginning in the first week, but not later, increased the number of axons converging at neuromuscular junctions. The effect of GDNF on the branching pattern of individual motor axons was determined by reconstructing labeled axonal arbors from transgenic mice expressing yellow fluorescent protein in subsets of motor neurons. Whereas, at postnatal day 8 (P8) individual axons in control animals branched to sporadically innervate junctions within circumscribed regions of the muscle, motor units from GDNF injected animals had significantly more axonal branches and exhibited a high degree of localized arborization such that adjacent muscle fibers were often innervated by the same axon. Administration beginning at PO and continuing through P40 prolonged multiple innervation of most fibers throughout the period of injection. Between P30 and P40 there was no net change in multiple innervation, although there was evidence of retraction bulbs, suggesting that axon extension and retraction were in equilibrium. We conclude that GDNF has a developmentally regulated effect on presynaptic branching and that sustained administration of GDNF induces a state of continuous synaptic remodeling.

Key words: GDNF; motor unit; motor neuron; growth factor; neuromuscular junction; synapse elimination; sprouting
A number of recent studies have demonstrated that neuronal growth factors influence synapses in many parts of the nervous system. For example, in autonomic ganglia, brain-derived neurotrophic factor (BDNF) has been shown to alter synaptic density, suggesting that growth factor levels regulate synaptogenesis (Causing et al., 1997). Activity-mediated synaptic rearrangements in the CNS are also influenced by BDNF and NT-4/5 (Cabelli et al., 1995, 1997). At the neuromuscular junction (NMJ), several trophic factors influence developmental synaptic rearrangements (English and Schwartz, 1995; Kwon et al., 1995; Jordan, 1996; Kwon and Gurney, 1996). Because evidence suggests that neuronal growth factors both influence synaptic activity and in turn can be regulated by neural activity, these factors may be mediators of activity-dependent synaptic plasticity (Ghosh et al., 1994; Li et al., 1998; Berninger et al., 1999; Kang and Schuman, 2000) (for review, see Snider and Lichtman, 1996; Schuman, 1999).

The actions of growth factors on synaptic connections could be indirect, because of effects on the degree of axon branching or on the number of axons (for example by preventing neuronal cell

\footnotetext{
Received Jan. 5, 2001; revised May 11, 2001; accepted May 24, 2001.

This work was supported by Grant R01 NS37873 from the National Institutes of Health.

Correspondence should be addressed to Dr. William Snider, Director, University of North Carolina Neuroscience Center, CB 7250, UNC School of Medicine, Chapel Hill, NC 27599. E-mail: wsnider@med.unc.edu.

G. Feng's present address: Department of Neurobiology, Duke School of Medicine, Durham, NC 27710.

Copyright (C) 2001 Society for Neuroscience $0270-6474 / 01 / 216136-11 \$ 15.00 / 0$
}

death). Alternatively, growth factors could directly influence synapse formation, maintenance, competition, or some combination. Deciding between these alternatives is complicated in the CNS, where both presynaptic and postsynaptic components may express receptors for the same trophic factor (McAllister et al., 1995, 1997).

Developing neuromuscular junctions undergo a stereotypical alteration in synaptic connections known as synapse elimination (Brown et al., 1976; Balice-Gordon et al., 1993), which seems analogous to central rearrangements, but is far easier to analyze. At the NMJ, transgenic overexpression of glial cell line-derived neurotrophic factor (GDNF), the most potent trophic factor yet described for motor neurons, leads to a dramatic increase in the number of motor axons innervating muscle fibers at a time when axons are ordinarily being eliminated (Nguyen et al., 1998). This effect suggested that GDNF might be an important regulator of synapse elimination. However, the interpretation of the mode of action of GDNF is ambiguous because transgenic GDNF expression began before the period of programmed cell death [approximately embryonic day 9.5 ( E9.5)] (Cheng et al., 1992), allowing GDNF to alter the number or behavior of motor axons while they are in the process of growing to targets.

Because the effects of transgenic GDNF on NMJ innervation are so dramatic and because an increased understanding of this effect may shed light on the regulation of synapses by growth factors, we thought it important to investigate the mechanism by which GDNF alters NMJ innervation. A pharmacological approach might provide useful information because exogenous ad- 
ministration can be used to control the amount, onset, and duration of GDNF exposure. We thus could ask if higher levels of circulating GDNF could maintain multiple innervation at the NMJ indefinitely, which did not occur in the transgenic animals expressing lower and uncontrolled levels of GDNF (Nguyen et al., 1998). We also could easily test whether GDNF-related molecules such as neurturin (NTN) (Kotzbauer et al., 1996; Klein et al., 1997; Milbrandt et al., 1998) had similar effects.

Here, we report that early postnatal subcutaneous injection of GDNF (but not NTN) induces sustained multiple innervation, but GDNF injections begun after the first postnatal week were without effect. Moreover, if GDNF administration is begun early, and continued into adulthood, multiple innervation persists. In these adult animals, there is evidence of ongoing synapse elimination despite the retention of multiple innervation. Morphological analysis of single labeled motor axons reveals that the hyperinnervation is quantitatively explained by an increase in motor unit size, not motor neuron number. Our results demonstrate that GDNF promotes axon branching and synapse formation at NMJs in postnatal life and, if applied during a developmentally restricted time, GDNF may induce a continuous state of synaptic remodeling.

\section{MATERIALS AND METHODS}

Protocol for injection of factors. Human recombinant (hr) GDNF was obtained from Amgen (Thousand Oaks, CA), and rat recombinant NTN was kindly supplied by G. Johnson (Washington University, St. Louis, $\mathrm{MO})$. Both growth factors were diluted to a working concentration of 2.5 $\mathrm{mg} / \mathrm{ml}$ in sterile $\mathrm{PBS}, \mathrm{pH} 7.4$. GDNF was stored at $-70^{\circ} \mathrm{C}$ until dilution, after which it was kept for a maximum of $4 \mathrm{~d}$ at $4^{\circ} \mathrm{C}$. Before injection, the skin was sterilized by wiping with $70 \%$ alcohol. Subcutaneous injections were done twice daily with a $10 \mu \mathrm{l}$ Hamilton syringe at a dose of 0.5 $\mu \mathrm{g} / \mathrm{gm}$ or $2.0 \mu \mathrm{g} / \mathrm{gm}$ in the back of the neck beginning on either postnatal day $0(\mathrm{P} 0)$ or P10. The volume of injection ranged from 0.2 to $20 \mu \mathrm{l}$. Injections continued until P8, P23, P30, or P40. Control injections were done identically to experimental injections, using PBS alone.

Animals. Timed pregnant CF-1 strain females were obtained from Charles River (Wilmington, MA). Thy1-YFP transgenic mice were produced at Washington University (St. Louis, MO) (Feng et al., 2000). The day of birth was considered postnatal day 0 . On the day of the terminal experiment, mice were deeply anesthetized with sodium pentobarbital $(0.65 \mathrm{mg} / \mathrm{gm}$ body weight $)$ and perfused transcardially with heparin in PBS, $\mathrm{pH} 7.4$, followed by $2 \%$ paraformaldehyde in $0.1 \mathrm{M}$ phosphate buffer, $\mathrm{pH}$ 7.4. Sternomastoid and spinotrapezius muscles were carefully dissected and post-fixed in paraformaldehyde for $\sim 2 \mathrm{hr}$. The connective tissue surrounding the muscle was then removed, and the tissue was incubated overnight in PBS with $0.1 \mathrm{M}$ glycine.

Tissue staining. Sternomastoid muscles from $\mathrm{CF} 1$ and spinotrapezius muscles from thy 1-YFP mice were incubated for $30 \mathrm{~min}$ at room temperature in $5 \mu \mathrm{g} / \mathrm{ml}$ tetramethylrhodamine-conjugated $\alpha$-bungarotoxin (Molecular Probes, Eugene, OR) that was diluted in $1 \%$ bovine serum albumin (BSA) in sterile lactated Ringer's solution. The muscles were then rinsed $3 \mathrm{hr}$ in PBS. Thy1-YFP spinotrapezius muscles were then mounted on glass slides in Vectashield mounting medium (Vector Laboratories, Burlingame, CA) for imaging. CF1 sternomastoid muscles were immunostained by blocking in $4 \%$ BSA and $0.5 \%$ Triton $\mathrm{X}-100$ in PBS overnight at $4^{\circ} \mathrm{C}$. The next day, muscles were incubated in mouse anti-phosphoneurofilament antibody SMI312 (Sternberger Monoclonals, Lutherville, MD) diluted 1:500 and the mouse synaptic vesicle antibody $\mathrm{SV}_{2}$ (Developmental Studies Hybridoma Bank, The University of Iowa, Department of Biological Sciences, IA City, IA) diluted 1:10 in blocking solution. After washing $5 \mathrm{hr}$ in $1.0 \%$ Triton X-100 in PBS, the tissue was incubated overnight in a 1:200 dilution of goat anti-mouse antibody conjugated to the fluorescent label Alexa 488 (Molecular Probes). Immunostained muscles were also mounted in Vectashield on glass slides.

Muscles to be stained for Ret or GFR $\alpha$-1 were dissected from unfixed animals, embedded in OCT (Tissue-Tek, Miles Inc., Elkhart, IN), and quick frozen with liquid nitrogen. Twenty micrometer sections through the endplate band were cut on a cryostat and thaw-mounted on glass slides for immunohistochemistry. Rabbit anti-Ret ( R \& D Systems,

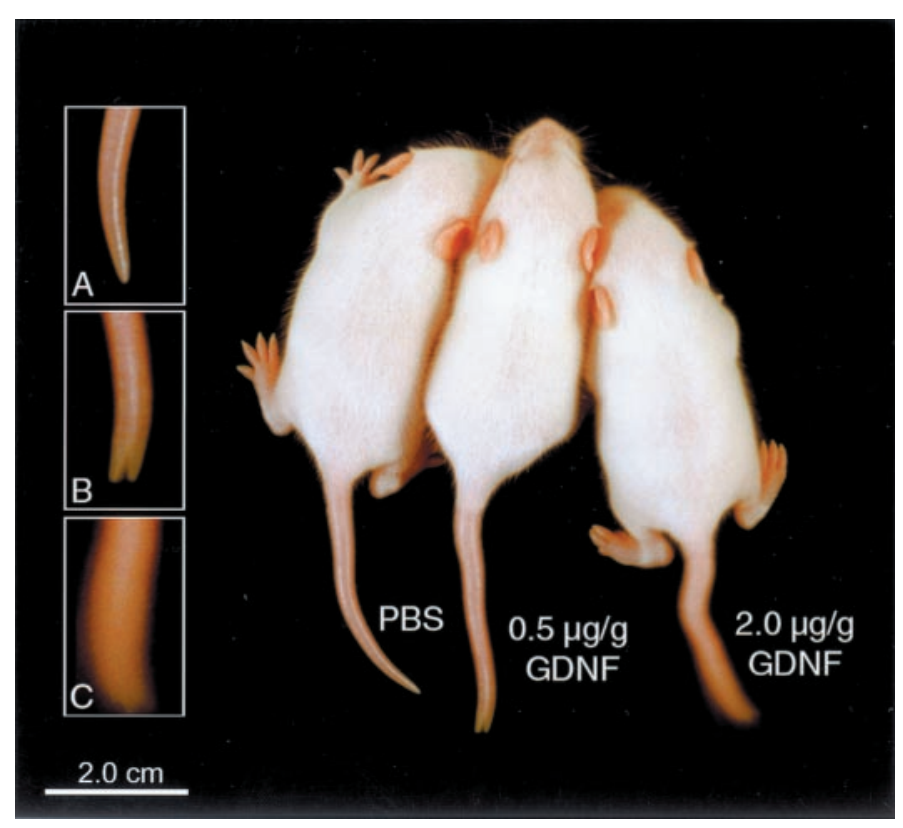

Figure 1. GDNF injection results in tail kinks, weight loss, and tremor. Three postnatal day 10 CF1 littermate pups are shown. Each pup was injected with PBS (left), $0.5 \mu \mathrm{g} / \mathrm{gm}$ GDNF (middle), or $2.0 \mu \mathrm{g} / \mathrm{gm}$ GDNF (right) beginning at birth. There is a dose-dependent increase in tremor, as noted in the insets (time lapse: $1 \mathrm{sec}$ exposure). $A$, PBS; $B, 0.5 \mu \mathrm{g} / \mathrm{gm}$ GDNF; $C, 2.0 \mu \mathrm{g} / \mathrm{gm}$ GDNF.

Minneapolis, MN) and goat anti-GFR $\alpha-1$ (KMI Diagnostics, Minneapolis, MN) were diluted 1:200 and 1:150, respectively, in blocking solution (see above). Tissue was incubated overnight at $4^{\circ} \mathrm{C}$. After washing in PBS, sections were incubated $3 \mathrm{hr}$ with either anti-rabbit or anti-goat secondary antibodies conjugated to Alexa 488 (Molecular Probes). After rinsing, slides were coverslipped with Vectashield (Vector Laboratories) and imaged.

Data collection. For each time period and each dose of growth factor, a minimum of two animals (four sternomastoid muscles) was examined. An approximately even distribution of male and female pups was used. When muscles from different animals in the same experimental condition were used, we first determined whether there were statistically significant differences within the group before combining data. In no case did muscles within an experimental group differ significantly from each other; therefore, " $n$ " in the text refers to the number of NMJs counted. Approximately 50 junctions per muscle were counted to determine the percent multiple innervation and the mean number of axons per receptor plaque. Data are expressed as the mean number of axons per muscle fiber \pm the $\mathrm{SD}$, unless otherwise noted.

A Nikon Optiphot microscope with a $50 \times$ water immersion lens was used to examine and count the number of axons per junction. Thy1-YFP single motor units (and Ret/GFR $\alpha$-1-labeled tissue sections) were imaged on an Olympus Optical (Tokyo, Japan) (BX50WI) microscope using a laser-scanning confocal microscope (model 1024; Bio-Rad, Hercules, CA). Images were obtained with a $40 \times(1.35 \mathrm{NA})$ oil objective. Z-stacks were flattened with Confocal Assistant, and montages of collapsed image stacks were assembled using Adobe Photoshop.

\section{RESULTS}

Initially, we tested daily subcutaneous doses of GDNF in newborn pups at $2.5 \mu \mathrm{g} / \mathrm{gm}$ and higher, but the animals rarely survived the first postnatal week. Therefore, to examine the effects of GDNF on neuromuscular junctions in postnatal life, we injected either 2.0 or $0.5 \mu \mathrm{g} / \mathrm{gm}$ GDNF twice daily into CF1 pups for periods $(8-40 \mathrm{~d})$ beginning at various time points after birth. Subcutaneous injection of either 2.0 or $0.5 \mu \mathrm{g} / \mathrm{gm}$ GDNF beginning at birth rapidly produced weight loss, and several days later tail kinks and tremors were evident (Fig. 1). These same characteristics were observed at birth in transgenic animals expressing 
Table 1. Number of axons per muscle fiber at various ages

\begin{tabular}{lllcr} 
& P0 & P8 & P23 & P30 \\
\hline PBS & $2.1^{a}$ & $1.4 \pm 0.5$ & $1.0 \pm 0.05$ & $1.0 \pm 0.1$ \\
GDNF $(0.5 \mu \mathrm{g} / \mathrm{gm})$ & " & $2.9 \pm 1.0$ & $1.5 \pm 0.6$ & $1.4 \pm 0.6$ \\
GDNF $(2.0 \mu \mathrm{g} / \mathrm{gm})$ & " & $3.3 \pm 1.1$ & $2.1 \pm 1.0$ & $1.7 \pm 0.7$ \\
NTN $(0.5 \mu \mathrm{g} / \mathrm{gm})$ & " & $1.4 \pm 0.5$ & ND & ND \\
NTN $(3.0 \mu \mathrm{g} / \mathrm{gm})$ & & $1.5 \pm 0.5$ & ND & ND \\
\hline
\end{tabular}

${ }^{a}$ Estimated from Balice-Gordon and Lichtman (1993).

ND, Not determined.
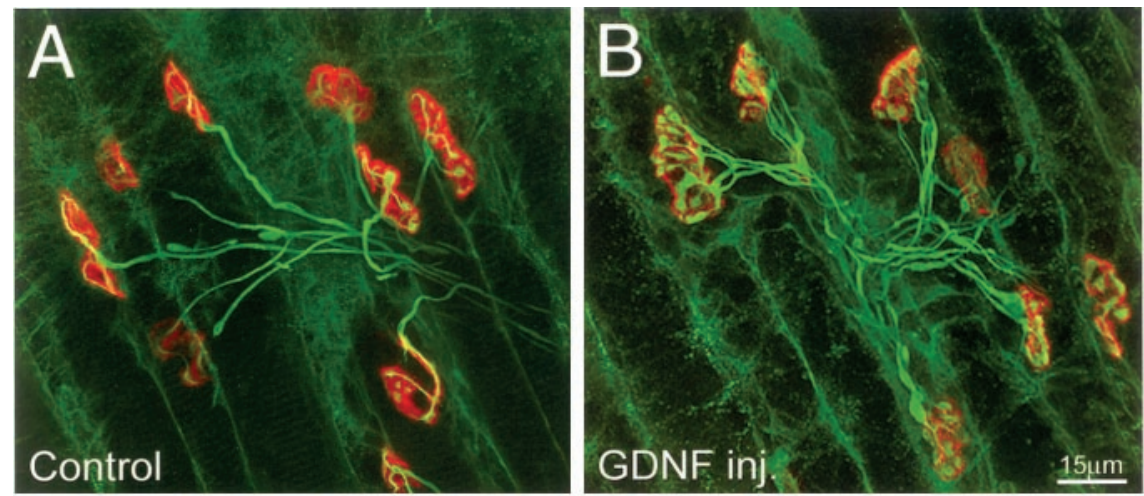

Figure 2. Postnatal GDNF injection produces hyperinnervation of neuromuscular junctions in sternomastoid muscle. $A, B$, Confocal reconstructions of part of the endplate band from a P8 mouse after twice-daily PBS $(A)$ or $2.0 \mu \mathrm{g} / \mathrm{gm}$ GDNF $(B)$ injections beginning at birth. $C, D$, Higher magnification confocal reconstructions of a single neuromuscular junction in control $(C)$ and GDNF-exposed $(D)$ sternomastoid muscles at P8. Four different axons innervate the junction in the GDNF-exposed mouse $(D$, arrows), whereas only one axon innervates the control junction $(C)$. Note that in the GDNF-exposed junction $(D)$, axon number 4 is relatively small compared with the other three inputs. Axons are labeled with anti-neurofilament antibodies ( green), and postsynaptic acetylcholine receptors are labeled with tetramethylrhodamine- $\alpha$-bungarotoxin (red).
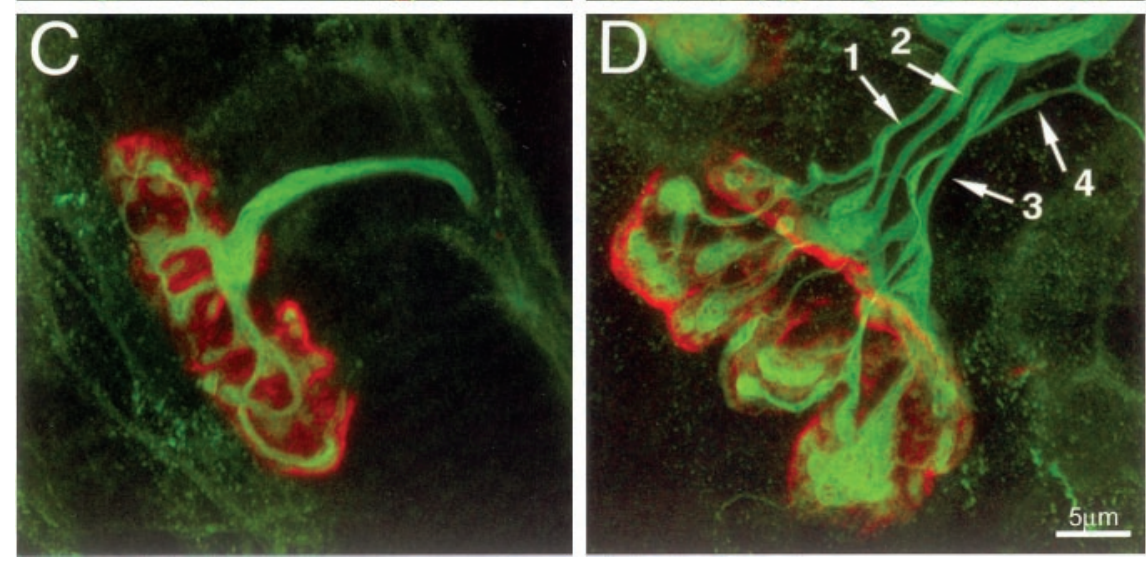

GDNF in muscles (Nguyen et al., 1998). Animals injected twice daily with $2.0 \mu \mathrm{g} / \mathrm{gm}$ GDNF for the first $7 \mathrm{~d}$ after birth weighed an average of $21 \%$ less than their PBS-injected littermate controls, and pups injected with $0.5 \mu \mathrm{g} / \mathrm{gm}$ for the same time period weighed an average of $2 \%$ less than controls. When the high dose GDNF injections were continued into later life (P0-P40), animals were $17 \%$ smaller than control P40 mice. The magnitude of tremor was higher and persisted longer in the mice injected with the higher dose of GDNF. Injection of the related factor, NTN, at doses of 3.0 or $0.5 \mu \mathrm{g} / \mathrm{gm}$ twice daily produced no external phenotypic changes.

\section{Effects of GDNF and NTN on neuromuscular innervation at P8}

In pups injected twice daily with saline from P0 through P8, 37\% of the sternomastoid muscle fibers were multiply innervated at P8 (mean $=1.4 \pm 0.5$ axons per NMJ; $n=411$ ). This number was significantly higher in pups injected from birth with $2.0 \mu \mathrm{g} / \mathrm{gm}$ GDNF; $99 \%$ of junctions at P8 were multiply innervated $($ mean $=$ $3.3 \pm 1.1 ; n=199 ; p<0.000001$; Student's $t$ test) (Table 1, Fig. $2 B$ ). However, after treatment many of the axons were of unusu- ally small caliber, and when adjacent to other axons, difficult to resolve, suggesting that we may have underestimated their number. In animals treated with the low, $0.5 \mu \mathrm{g} / \mathrm{gm}$, GDNF dose, the incidence of multiple innervation $(93 \%)$ and average number of axons per NMJ (mean $=2.9 \pm 1.0 ; n=318$ ) was also significantly greater than controls ( $p<0.000001$; Student's $t$ test). The effect of the low dose of GDNF was however, significantly less than the effects of the high dose of GDNF ( $p=0.0002$; Student's $t$ test). We surveyed several other muscles in the GDNF-treated animals, including two in the hindlimb (gastrocnemius and soleus), and found similar effects on multiple innervation.

Injection of the related factor neurturin at $0.5 \mu \mathrm{g} / \mathrm{gm}$ had no effect on the number of axons innervating muscle fibers, and injection of $3.0 \mu \mathrm{g} / \mathrm{gm}$ produced no significant increase in NMJ innervation at P8 $(1.5 \pm 0.5 ; n=122)$ (Table 1$)$. These results show that augmenting GDNF levels, but not NTN, in postnatal animals had comparable effects to transgenic GDNF expression beginning in embryonic life.

Interestingly, the number of axons per junction in $\mathrm{P} 8$ pups after GDNF injection of 2.0 or $0.5 \mu \mathrm{g} / \mathrm{gm}$ is $>2.1$ axons per junction 
estimated from electrophysiological studies of wild-type sternomastoid muscle at P0 (Balice-Gordon and Lichtman, 1993), suggesting that GDNF is able to induce presynaptic branching.

\section{Presynaptic branching}

To directly assess the effect of GDNF on motor neuron morphology, we examined the entire branching pattern of single motor units in P8 muscles after twice-daily injections of $2.0 \mu \mathrm{g} / \mathrm{gm}$ GDNF beginning at birth. To analyze individual motor units, we used a line of transgenic mice (thyl-YFP) that expresses yellow fluorescent protein (YFP) in only a few motor neurons per motor pool during postnatal life (Feng et al., 2000) (our unpublished observations). For this study, we chose the spinotrapezius muscle because it is a thin muscle (unlike the sternomastoid, which was used previously) that is ideal for imaging the entire arbor of individual motor axons. In control muscles, each motor axon enters the muscle rostrally and sends off branches as it courses caudally (Fig. $3 A$ ). At P8, labeled motor units in control animals contact an average of $55 \pm 15(n=5)$ muscle fibers. After GDNF injection, the size of single motor units more than doubled, with each axon contacting an average of $112 \pm 18$ muscle fibers at P8 $(n=2 ; p=0.008)$ (Fig. $3 B, C)$. Thus, GDNF exposure in postnatal life leads to a large-scale increase in the size of motor units.

To determine if the degree of expansion of GDNF-injected motor units was consistent with the degree of multiple innervation in spinotrapezius muscle, we analyzed individual junctions from single motor units in GDNF-injected and control animals. The YFP-labeled axon occupies all the acetylcholine receptors in junctions that are singly innervated. In contrast, junctions that have not completed synapse elimination are only partially occupied by the labeled axon (our unpublished observations). Thus, by analyzing the degree of receptor occupation, it is possible to determine the percentage of endplates that are still multiply innervated in a motor unit. In the control muscles at P8, $\sim 75 \%$ of spinotrapezius neuromuscular junctions had completed synapse elimination and were singly innervated. In the GDNF-treated muscles, $15 \%$ of the NMJs were singly innervated $(p<0.001 ; z$ test). If the remaining $85 \%$ of multiply innervated junctions had just two axons innervating them, there would be an average of 1.75 axons per junction. This number is consistent with the approximately twofold increase in the size of motor units.

We also analyzed the particular branching patterns of individual motor axons after GDNF injection (Fig. 4). To do this, we began by counting the number of axonal branch points between the cell body and each NMJ. In control animals, each neuromuscular contact in a motor unit was an average of 11.12 branch points from the cell body. Each NMJ in GDNF-injected animals was an average of 11.48 branch points from the cell body. Furthermore, the most distal NMJ in controls was found 26 branch points from the cell body (mean $=19$ ), whereas the most distal NMJs in GDNF motor units were found up to 22 branch points from the cell body (mean $=19)$. Thus, GDNF exposure affects the branching of motor units in such a way that uniform expansion of the motor unit is produced.

One way this uniform effect could occur is if GDNF caused terminal axon branches (those branches directly contacting endplates) to bifurcate. In contrast to controls, terminal branches in the GDNF-exposed animals often innervated multiple neighboring muscle fibers. For example, within a single $60 \mu \mathrm{m}^{2}$ field of view from a GDNF-treated P8 mouse, in which at least one labeled terminal branch was present, two or three NMJs innervated by the same labeled motor axon could be visualized 20 or
$12 \%$ of the time, respectively. In PBS-injected motor units, two NMJs were infrequently observed in a single field of view (8\%), and three were never observed. The increase in the number of double- and triple-labeled neuromuscular junctions within a single field of view after GDNF exposure was significant $(p<0.001$ in both instances). To control for the possibility that more labeled endplates were visible in a single field of view because the muscle fibers were smaller after GDNF injection, we counted the total number of receptor plaques in each field of view. Per field, the total number of endplates was not significantly different between GDNF and the control (1.7 vs 1.8, respectively). Taken together, these data suggest that the increase in motor unit size after GDNF injection occurs by increased terminal branching.

\section{Synaptic maintenance}

For the reasons described above, the larger motor units seen in GDNF-treated mice seem to be attributable at least in part to an induction of axonal branching. However, it is also plausible that GDNF alters synapse survival and thereby allows more of the initially formed branches to be maintained during the period of synapse elimination. One objective of this study was therefore to determine whether sufficiently high concentrations of GDNF could maintain multiple innervation. We injected GDNF at 2.0 or $0.5 \mu \mathrm{g} / \mathrm{gm}$ from $\mathrm{P} 0$ until P23, P30, or P40. The results are shown in Table 1.

Despite the twice-daily dose of injected GDNF, the number of axons per fiber decreased as the animal matured. Furthermore, even at postnatal day 8 , the first time period examined, some branches of a motor unit had completed synapse elimination (Fig. 4). These results suggest that GDNF by itself is unable to maintain the high level of multiple innervation observed during the first postnatal week, and therefore GDNF cannot prevent synapse elimination from occurring. However, when compared with control animals, significantly more multiple innervation was evident in mice injected with GDNF $(2.0 \mu \mathrm{g} / \mathrm{gm})$ through P40 (1.8 \pm 0.8 ; $n=184)$ compared with uninjected mice $(1.0 \pm 0 ; n=81 ; p<$ 0.000001 ; Student's $t$ test). In the presence of a continual supply of GDNF, a plateau was reached at P30, because there was no significant difference between the number of axons per fiber at P30 (1.7 $\pm 0.7 ; n=245)$ and P40 (1.8 $\pm 0.8 ; n=184 ; p>0.09$; Student's $t$ test). Despite no change in the number of multiply innervated fibers from P30 to P40, chronic GDNF exposure starting at birth was still affecting neuromuscular junction innervation at these late ages because discontinuation of GDNF administration at P30 caused the number of multiply innervated neuromuscular junctions to drop to an average of $1.4 \pm 0.8(n=$ 87 ) by the age of P40. This result is interesting because GDNF treatments begun after P10 had no effects on neuromuscular innervation at any age (see below).

In chronically treated mice, multiple innervation of junctions always decreased after withdrawal of GDNF (Fig. 5). For example, stopping GDNF injections at P10 resulted in a 30\% decrease in the number of axons per NMJ at P23 compared with continual injection from $\mathrm{P} 0$ to $\mathrm{P} 23$. Moreover, this decrease was statistically significant ( $p<0.000001$; Student's $t$ test). Discontinuing GDNF injection at $\mathrm{P} 10$ and examining junctions at $\mathrm{P} 30$ also produced a significant $(30 \%)$ decrease in the number of axons per junction compared with continual injection ( $p<0.000001$; Student's $t$ test). Finally, when GDNF injection is discontinued at P10 and the number of axons per junction counted at P40, the level of multiple innervation begins to approach that of control, PBSinjected muscles (i.e., $1.0 \pm 0$ ). Specifically, at P40, 38\% fewer 

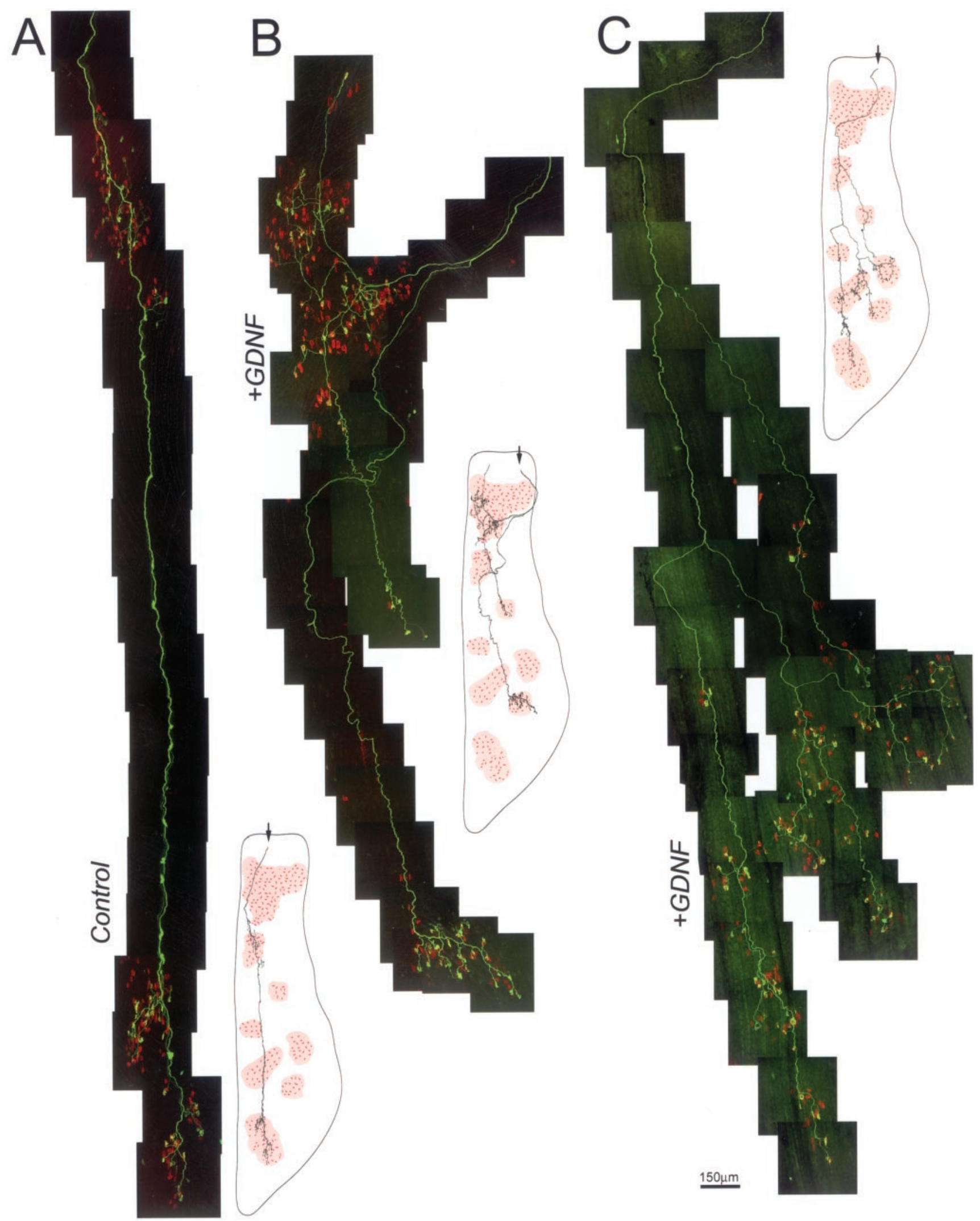

Figure 3. Completely reconstructed motor units in postnatal day 8 spinotrapezius muscle show a twofold increase in branching after GDNF injection. Montages of confocal reconstructions from postnatal day 8 transgenic mice $($ thyl-YFP) reveal single motor axons that express yellow fluorescent protein. Axons appear green, and acetylcholine receptors are labeled with rhodamine- $\alpha$-bungarotoxin $(r e d)$. The expanse of each motor unit is shown in the small diagram to the right of each photomontage. The pink patches in the diagrams are areas where neuromuscular junctions are clustered. $A$, Control motor units, such as the one shown, are relatively simple. $B, C$, In contrast, GDNF-exposed motor units $(2.0 \mu \mathrm{g} / \mathrm{gm}$ GDNF) are more complicated. The control motor unit in $A$ formed 57 neuromuscular contacts. The GDNF motor unit in $B$ formed 99 neuromuscular contacts, and the motor unit in $C$ formed 124 . 

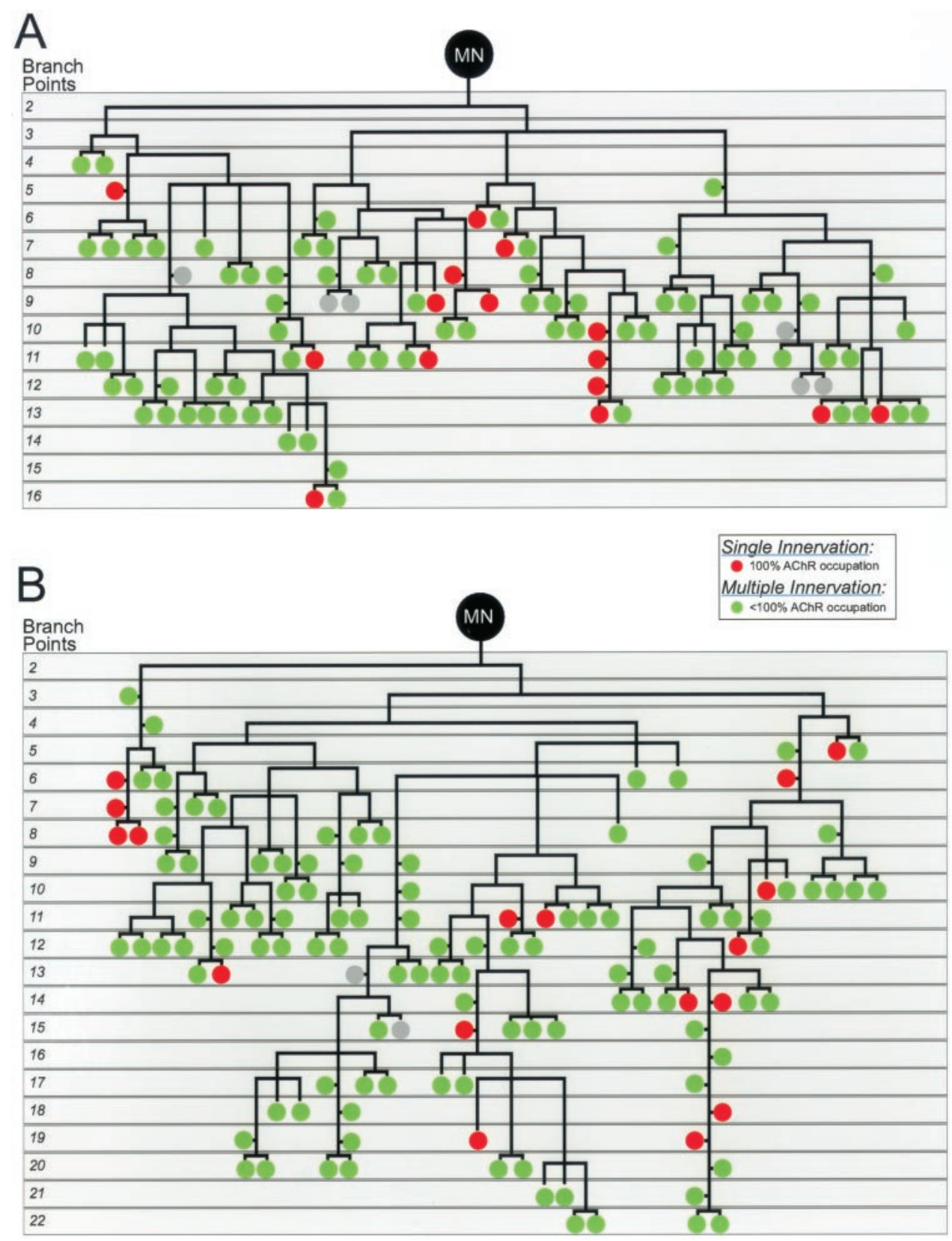

Figure 4. Branching diagrams for two motor units after GDNF injection show expansion of the motor unit around the cell body ( $A$ is the motor unit shown in Fig. $3 B$, and $B$ is the motor unit shown in Fig. $3 C$ ). The number of branch points between each neuromuscular junction and the cell body $(M N)$ is shown to the left of each diagram. The junctions are colorcoded so that singly innervated NMJs (i.e., those that have completed synapse elimination) are red, and junctions that are partially occupied, and therefore multiply innervated, are green. Gray circles indicate junctions that were oriented such that we could not determine whether or not they had completed synapse elimination. axons innervate NMJs when GDNF is stopped at P10 than when GDNF is not stopped until examination $(p<0.000001$; Student's $t$ test). These data indicate that a continual supply of GDNF is required to exert long-term effects on neuromuscular innervation.

\section{Continuous branch remodeling is induced by GDNF}

To better understand how GDNF caused persistent multiple innervation, we examined confocal images of labeled sternomastoid and spinotrapezius preparations from P8 to P40 for the presence of retraction bulbs (very thin axons with bulbous endings) and sprouts, in mice treated with GDNF from birth. As expected, given the decrease in the number of axons per junction after the first postnatal week, many retraction bulbs were observed in GDNF-treated animals. Interestingly, numerous retraction bulbs were present at both P30 and P40 (Fig. 6B), despite the fact that the number of axons per fiber did not decrease during this period, implying that axons may have been both retracting and re-growing. Consistent with this view, terminal and nodal sprouts were present throughout postnatal life after GDNF administration (Fig. $6 C-H$ ). These results suggest that a dynamic state of active axon growth and retraction may be occurring in the presence of GDNF.

While examining the innervation of junctions in GDNF injected pups, we also noted that many of the receptor sites appeared morphologically abnormal compared with littermate controls. In neonatal pups $<2$ weeks of age, acetylcholine receptors (AChRs) tend to be clustered in smooth, oval plaques. As the animal matures, these plaques increase in size and become perforated, transforming the plaque into a "pretzel-like" morphology (Marques et al., 2000). At P8, AChR plaques from GDNFtreated mice $(2.0 \mu \mathrm{g} / \mathrm{gm})$ were significantly larger in both area $(30 \% ; p<0.001)$ and length $(20 \% ; p<0.001)$ (Fig. $7 A)$. This increase in size occurred despite the fact that the mice are smaller 


\begin{abstract}
Figure 5. Continual GDNF injection is required to maintain multiple innervation. Graph showing the effects of discontinuing GDNF injection at postnatal day 10 (hatched bars) compared with continual injection (black bars). We injected $2.0 \mu \mathrm{g} / \mathrm{gm}$ GDNF in all animals beginning at birth. When GDNF is discontinued at postnatal day 10 (hatched bars), synapse elimination rapidly proceeds, and by postnatal day 40 ( far right, hatched bar) the number of axons per junction has almost reached control levels (1.0 axons/NMJ). In animals receiving GDNF injection from $\mathrm{P} 0$ to $\mathrm{P} 10, n=$ 203, 199, and 150 at P23, P30, and P40, respectively. In animals receiving GDNF injection from $\mathrm{P} 0$ until examination, $n=309,244$, and 183 at P23, P30, and P40, respectively. Asterisks indicate statistically significant differences (see Materials and Methods). Error bars indicate mean $\pm \mathrm{SE}$.
\end{abstract}

at P8 than control (see above). Interestingly, by postnatal day 30, the effect had reversed. After injection of $2.0 \mu \mathrm{g} / \mathrm{gm}$ GDNF, AChR clusters were now significantly smaller and much simpler than the age-matched controls. In the $2.0 \mu \mathrm{g} / \mathrm{gm}$-injected animals at $\mathrm{P} 30$, receptor plaques were $23 \%$ smaller in area $(p<0.001)$ and $20 \%$ smaller in length $(p<0.001)$ than the control (Fig. $7 B-D)$. In addition, the number of AChR-containing branches within a neuromuscular junction was fourfold lower in the GDNF-treated animals (mean $3.2 \pm 1.6$ branches) than in controls (mean $11.8 \pm 2.0$ branches) at P30. In the low-dose animals, the receptors were $12 \%$ smaller in area and $19 \%$ smaller in length. Thus, despite the ability of GDNF to induce hyperinnervation and larger postsynaptic AChR sites in early postnatal life, prolonged synaptic remodeling seemed to ultimately have deleterious effects on the AChR areas. Perhaps repeated volleys of synaptic withdrawal, induced by GDNF, caused an exaggeration of the naturally occurring AChR loss seen during the period of naturally occurring synapse elimination in early postnatal life (for review, see Lichtman and Colman, 2000).

\section{Developmentally restricted responses to GDNF}

To determine whether motor neurons were equally responsive to GDNF at all ages, GDNF was injected twice daily starting at P10 rather than at $\mathrm{P} 0$, and the number of axons per NMJ was examined at P23. Surprisingly, injections begun at P10 resulted in no polyneuronal innervation $(1.0 \pm 0 ; n=205)$, and in fact the NMJs were indistinguishable from those in animals injected with PBS alone. Moreover, tail kinks and tremor were not observed when injections were begun at P10. The inability of motor neurons to respond to GDNF injection after P10 thus marks the end of a critical period of susceptibility in motor neuron development that approximates the end of naturally occurring synapse elimination. This implies that continual exposure to GDNF from birth prevents motor axons from maturing appropriately, and therefore permits axons to maintain their responsiveness to GDNF.

One possible explanation for the decreased ability of GDNF to induce branching after postnatal day 10 is that axonal responsiveness to GDNF diminishes, perhaps because GDNF receptor components are no longer present on axons after the first postnatal week. Substantial evidence exists that motor neuron cell

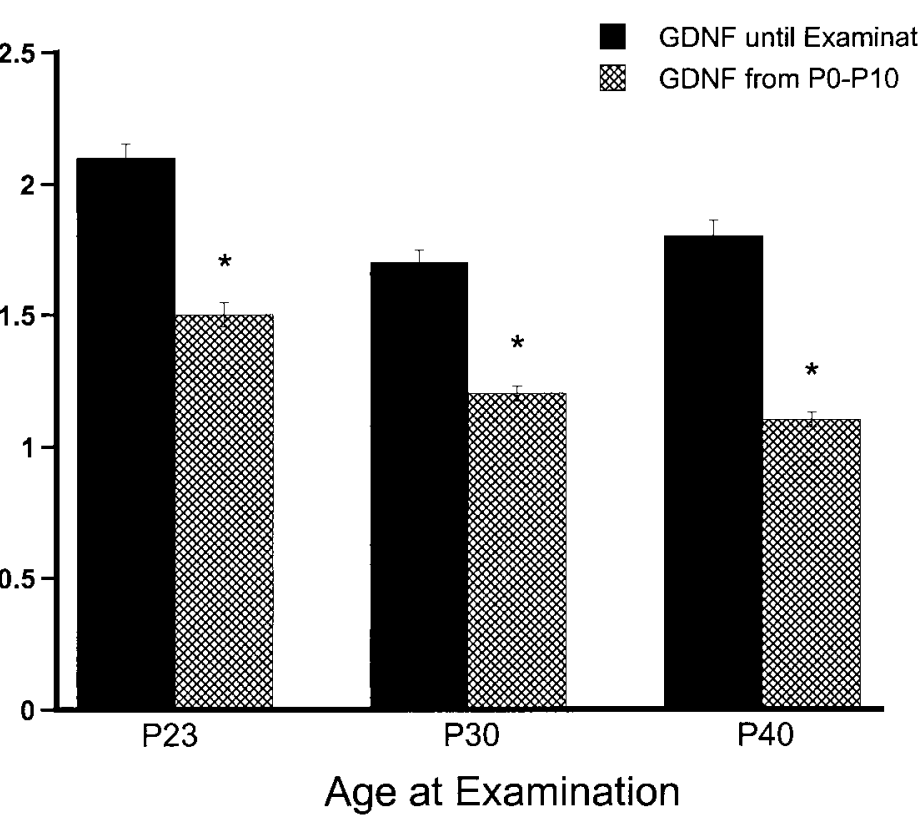

bodies continue to express both the Ret and GFR $\alpha-1$ components of the GDNF receptor into adulthood (Golden et al., 1998). Nonetheless, it is unknown whether these receptors are also present on axons in adulthood. To test the possibility that GDNF receptors are excluded from intramuscular axon branches after the first postnatal week, we immunostained P2, P14, and adult sternomastoid muscles for both Ret and GFR $\alpha-1$. Strong Ret label was detected at the neuromuscular junctions at all ages studied. The labeling appeared presynaptic, although terminal Schwann cell staining could not be excluded. Weak labeling of the intramuscular nerves was also observed at all ages. The result was similar for GFR $\alpha-1$; labeling was detected at the neuromuscular junction at all ages (although it was substantially weaker than the Ret staining). Strong GFR $\alpha-1$ staining was found in the intramuscular nerves at the same three ages. These results suggest that the components for functional GDNF receptors persist in motor axons as the animals mature, and therefore the lack of responsiveness of motor neurons to exogenously applied GDNF after postnatal day 10 is unlikely to be explained by receptor redistribution.

\section{DISCUSSION}

The GDNF family of polypeptide growth factors has multiple regulatory roles during neural development in many ways analogous to those of the neurotrophins (for review, see Baloh et al., 2000). GDNF is the most potent neuronal growth factor described for developing motor neurons both in vitro (Henderson et al., 1994) and in vivo (Li et al., 1995; Oppenheim et al., 1995; Yan et al., 1995). The biological action of GDNF is mediated by a two-component receptor complex that consists of a ligand binding glycosylphosphatidylinositol-linked cell surface protein, GFR $\alpha-1$ (Jing et al., 1996; Treanor et al., 1996), and a receptor tyrosine kinase encoded by the c-Ret proto-oncogene (Ret; Durbec et al., 1996; Trupp et al., 1996). Consistent with its trophic effects on motor neurons, GDNF is expressed in developing nerves and skeletal muscle at the time axons project to, and branch in, muscle fibers (Trupp et al., 1995; Nosrat et al., 1996). Additionally, motor neurons express the two-component GDNF receptor complex 

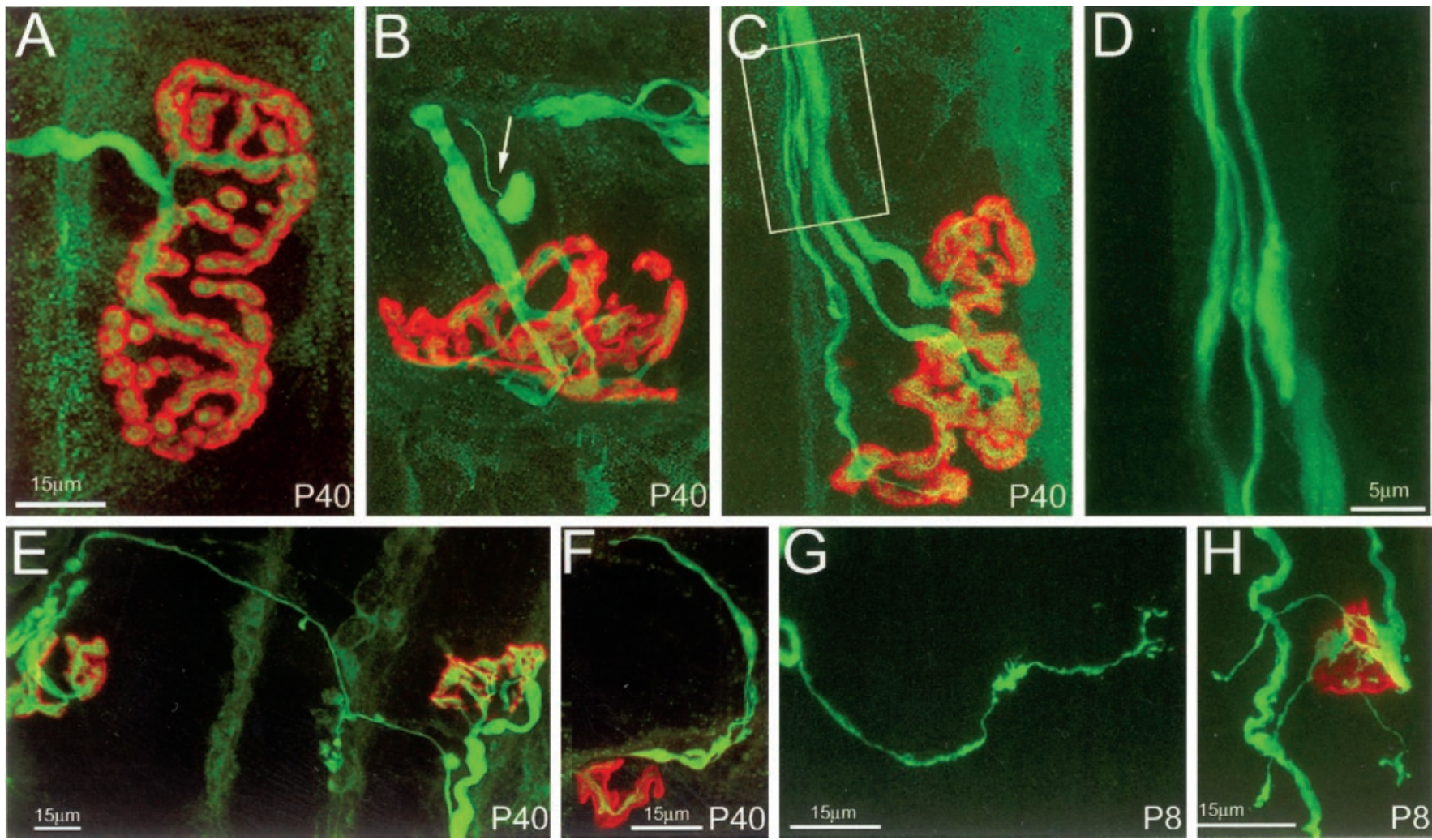

Figure 6. GDNF induces a dynamic state of axonal branching. A, Confocal reconstruction of a neuromuscular junction from control sternomastoid muscle at P40 shows that the junctions are large, singly innervated, and have a complicated pattern of receptor branches that accurately mirrors the branching pattern of the overlying terminal axon, which possesses no sprouts. $B, C$, In contrast, after $40 \mathrm{~d}$ of continual exposure to $2.0 \mu \mathrm{g} / \mathrm{gm}$ GDNF, junctions are often multiply innervated $(C)$, smaller in area, and somewhat less complex than controls. Furthermore, many thin axons, terminating in bulbs, were evident (arrow, B). These structures are identical in appearance to "retraction bulbs" seen during naturally occurring synapse elimination in the first 2 postnatal weeks (Bernstein and Lichtman, 1999). Additionally, axons that ended in structures that resembled growth cones were observed in GDNF-exposed muscles $(C$, and enlargement shown in $D) . E, F$, Also observed at P40 in GDNF-treated muscles were terminal sprouts that either connected nearby junctions $(E)$ or exited neuromuscular junctions but ended blindly $(F) . G, H$, Such sprouting was also seen at earlier ages. Shown here $(G)$ is a blindly ending sprout off a YFP-labeled axon from a P8 spinotrapezius muscle in a mouse treated with GDNF since birth and a neuromuscular junction with three terminal sprouts $(H)$ from the same animal, suggesting that throughout the duration of GDNF exposure axons were sending out new processes in the muscle. Scale bar shown in $A$ is the same for $B$ and $C$. In $A-F$, axons are labeled with anti-neurofilament antibodies (green), and postsynaptic acetylcholine receptors are labeled with rhodamine- $\alpha$-bungarotoxin (red).

(Pachnis et al., 1993; Tsuzuki et al., 1995; Naveilhan et al., 1997; Trupp et al., 1997), including the ligand-binding component GFR $\alpha$-1 (Jing et al., 1996; Treanor et al., 1996) and the signaltransducing component Ret tyrosine kinase (Durbec et al., 1996; Trupp et al., 1996). The expression of GDNF and its receptors strongly suggests that GDNF is an important target-derived factor for spinal neuron survival, differentiation, and/or synaptic remodeling.

In this study, we have shown that augmentation of GDNF levels by subcutaneous injection in the postnatal period results in hyperinnervation of neuromuscular junctions. This effect is quite similar to that obtained by target mediated delivery of GDNF (Nguyen et al., 1998), indicating that a localized postsynaptic target supply of growth factor is not required for its effects on synapses. We have found that the hyperinnervation is entirely explained by an increase in the overall size of single motor units, such that they are twice as large as control motor units at P8. Therefore, these results show that in addition to the effects of GDNF on motor neuron survival in embryonic life (Oppenheim et al., 2000), GDNF also has potent effects on axonal arbors in postnatal life. Continued administration of GDNF is required to maintain the multiple innervation at later ages. Nevertheless, synapse elimination still proceeds to some degree even in the presence of high levels of GDNF, suggesting that GDNF likely plays a minimal role in maintaining synapses. Moreover, analysis of morphological changes in both the axon and the receptor area suggests that a dynamic remodeling of neuromuscular junctions occurs in the presence of exogenous GDNF. Finally, we have shown that this effect of GDNF is developmentally restricted, because even very high doses of exogenous GDNF do not produce multiple innervation if administration is begun after P10.

GDNF injections also altered the animal's external appearance. When GDNF was begun in the first postnatal week, tail kinks and tremor were observed but not when injections were begun later. These outward signs correlated with the morphological changes in axon branching (i.e., higher doses of GDNF produced more multiple innervation at $\mathrm{P} 8$, and also a greater degree of tremor). It is possible that both the tremor and the tail kinks are attributable to the larger size of motor units produced by GDNF. Each motor unit, because of its increased size, would cause significantly more noticeable muscle twitching when the motor axon was stimulated, leading to a tremor. The tail kinks may derive from unbalanced muscle tone because of a greater 
A

Figure 7. Acetylcholine receptor plaques are abnormal in GDNFinjected animals. $A$, Average area (left) or length (right) of acetylcholine receptor plaques at $\mathrm{P} 8$ after continual exposure to either GDNF (white bars) or PBS (black bars). The small inset in $A$, left, shows the size frequency histogram of acetylcholine receptor area in P8 GDNF-exposed animals (white bars) compared with control (black bars). At $\mathrm{P} 8$, receptor plaques are larger $(p<0.001)$ and longer $(p<$ 0.001 ) after GDNF injection than in control muscles. $B$, Average area (left) or length (right) of acetylcholine receptor plaques at P30 after continual exposure to either GDNF (white bars) or PBS (black bars). At P30, AChR plaques in GDNF-injected sternomastoid muscles are now significantly smaller than controls in area $(p<$ $0.001)$ and length $(p<0.001)$ and are also less complex (see below). $C, D$, Photomicrographs of $\mathrm{P} 30$ receptor plaques. $C$, AChRs in control junctions show many small perforations and bifurcations. $D$, High doses $(2.0$ $\mu \mathrm{g} / \mathrm{gm})$ of GDNF decrease the complexity and size of the receptor area. One of every six junctions $(n=30)$ that were photographed is shown from least complex to most complex (left to right). Error bars indicate mean $\pm \mathrm{SE}$.
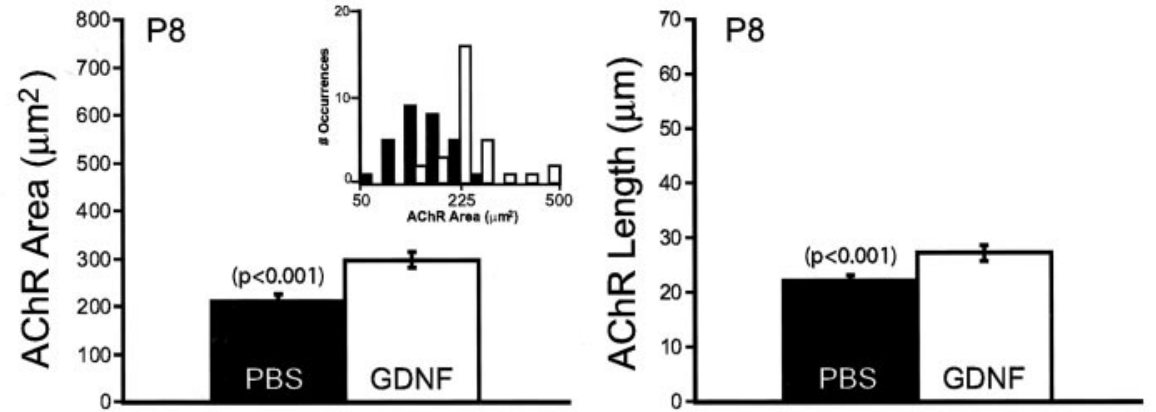

B
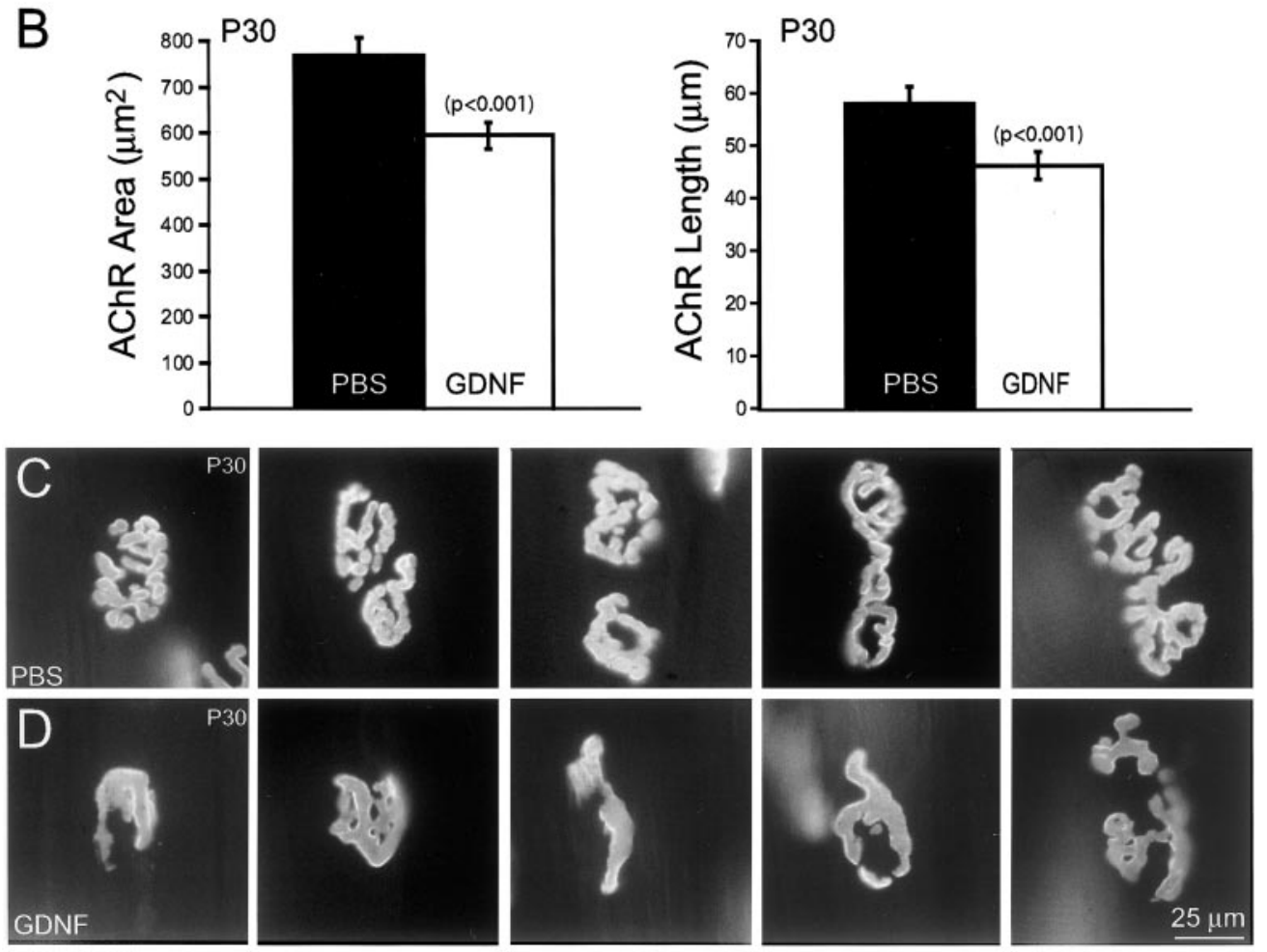

number of muscle fibers activated by some motor neurons innervating tail musculature.

\section{GDNF and synaptic rearrangements}

In previous work, a significant effect of transgenically supplied GDNF on the number axons innervating the NMJ was shown (Nguyen et al., 1998). In Myo-GDNF mice the transition from multiple innervation to single innervation was delayed by $\sim 2$ weeks. One interpretation of this work is that neuronal growth factors somehow stabilize synapses and prevent the rearrangements that would ordinarily occur. The present results suggest however that the effect is predominantly by induction of axonal branches.

Two quantitative and three morphological lines of evidence support this view. First, the degree of multiple innervation induced by GDNF at P8 is greater than the degree of multiple innervation at $\mathrm{P} 0$, as determined by physiological methods (Balice-Gordon and Lichtman, 1993). Furthermore, because of the small caliber and tight fasciculation of axons at P8, we undoubtedly underestimated the degree of multiple innervation induced by GDNF. Second, even in the face of high levels of circulating GDNF, the number of axons per receptor plaque declined almost $50 \%$ as the animal matured (from 3.3 at P8 to 1.8 at P40). These data suggest that GDNF is unable to maintain synaptic connections.

There is also a significant amount of morphological evidence that synapse elimination is continuing in the presence of GDNF. First, endplates were markedly smaller than normal at P30, suggesting that synaptic remodeling was ongoing, because synapse loss has been associated with AChR loss (Lichtman and Colman, 2000). Second, in 1-month-old animals exposed to GDNF from birth, retraction bulbs, structures that are specifically associated with synaptic withdrawal during the period of normal synapse elimination (Bernstein and Lichtman, 1999), were frequently encountered in the endplate band. At normal adult NMJs there is no evidence of synaptic rearrangement. Third, sprouts, and other larger caliber axons not contacting endplates, were sometimes found in mature muscles after GDNF exposure. The combination of both presynaptic and postsynaptic changes suggests that the effect of GDNF is to induce a continual state of sprouting and elimination that results in a situation in which some fraction of the endplates are multiply innervated at every observation.

\section{Specificity and temporal responses to GDNF}

The specificity of morphological changes for GDNF is an interesting feature of our results. Motor neurons express receptors for 
multiple neurotrophins, GDNF family, cytokine, and other growth factors (Henderson et al., 1998). However, our results here show that subcutaneous injection of the GDNF family member neurturin at $3.0 \mu \mathrm{g} / \mathrm{gm}$ does not produce multiple innervation, and it has been previously shown that transgenically oversupplied NT-3 and NT-4 were also ineffective (Nguyen et al., 1998). Furthermore, the use of adenoviruses to deliver truncated trk receptors to scavenge neurotrophins has shown primary effects on muscle fibers and Schwann cells, rather than direct effects on motor axons (Gonzalez et al., 1999). In vitro, GDNF has shown more robust growth-promoting effects on motor axons than any other factor (Henderson et al., 1994; Ho et al., 2000). At the moment there is no clear-cut explanation for the specificity of the morphological responses to GDNF. These results suggest that that Ret (and not the trks) activates signal transduction mediators specifically linked to morphological responses in motor neurons. One of the effects of the neurotrophins at the neuromuscular junction may be to regulate assembly of postsynaptic receptors (Yan et al., 1995; Gonzalez et al., 1999).

Whereas GDNF induced extensive growth of axons, these increased branches were constrained to the endplate band. A possible explanation of this lack of widespread exuberant growth is that the motor axon branches may be restricted to grow along Schwann cells and that the growth effect does not encourage axons to escape from their glial sheaths (Son and Thompson, 1995a,b). These morphological responses raise the issue of the role of GDNF in regeneration. After axotomy there is a dramatic upregulation of GDNF by Schwann cells and muscle (Trupp et al., 1995, 1997; Naveilhan et al., 1997). Furthermore, injection of the GDNF gene in individual muscle fibers produces considerable motor axon growth and branching (Bernstein et al., 1998; our unpublished observations). These data are consistent with the idea that GDNF promotes a more rapid regenerative response (Naveilhan et al., 1997). However, our results raise the possibility that GDNF regulation of regeneration is more related to terminal branching than to extension of axons down a damaged nerve.

The branching pattern of motor axons observed in GDNFtreated mice suggested that the effect of GDNF was primarily on terminal branches. If GDNF had caused motor axons to undergo a greater number of proximal bifurcations, then the number of branch points between each endplate and the cell body would have been increased. However, the average number of branch points remained the same (although the total number of NMJs contacted by the motor axon increased twofold). Thus, the added neuromuscular junctions must have come from terminal branches.

The temporal restriction of GDNF effects is also of considerable interest. We saw no effect on motor axon branching if GDNF was first administered after postnatal day 10. Adult motor neurons continue to express Ret and should in theory respond to GDNF (Golden et al., 1998). A spatial exclusion of Ret from axon terminal regions is a plausible explanation for the loss of axon responsiveness. However, we have found that there is no detectable difference in the expression of GDNF receptors in the intramuscular branches of motor axons between P2 and adulthood. Presumably the difference in GDNF responsiveness with age is downstream of the receptor per se. Thus, the change in GDNF reactivity may reflect a broader downregulation of axon growth potential as neurons mature. In this regard it should be noted that sensory neurons when initially plated in culture do not respond with axon elongation unless they have been previously axotomized (Smith and Skene, 1997). In other work we have shown that axotomy restores the ability of motor axons to respond with growth and branching to GDNF (Bernstein et al., 1998; our unpublished observations). This may explain why GDNF has persistent effects after P8 when started early: axons may remain in a growth state in its presence and thus remain sensitive to the factor.

\section{Conclusions}

Here, we sought to maintain high levels of GDNF through pharmacological means to test the premise that competition for a growth factor in limited supply would be inhibited by excess growth factor, and therefore a powerful motor neuron growth factor might prevent synapse elimination. However, our results suggest that the role of GDNF is in growth and branching, and therefore synapse loss may more likely be regulated by other kinds of signals such as those that maintain and disrupt the adhesion of the nerve to the postsynaptic site. Nonetheless, GDNF appears to have extremely potent effects on axonal branching and synapse formation in early postnatal life, and these effects can persist into adult life when GDNF exposure is maintained.

\section{REFERENCES}

Balice-Gordon RJ, Lichtman JW (1993) In vivo observations of pre- and postsynaptic changes during the transition from multiple to single innervation at developing neuromuscular junctions. $J$ Neurosci 13:834-855.

Balice-Gordon RJ, Chua CK, Nelson CC, Lichtman JW (1993) Gradual loss of synaptic cartels precedes axon withdrawal at developing neuromuscular junctions. Neuron 11:801-815.

Baloh RH, Enomoto H, Johnson EMJ, Milbrandt J (2000) The GDNF family ligands and receptors - implications for neural development. Curr Opin Neurobiol 10:103-110.

Berninger B, Schinder AF, Poo MM (1999) Synaptic reliability correlates with reduced susceptibility to synaptic potentiation by brainderived neurotrophic factor. Learn Mem 6:232-242.

Bernstein M, Lichtman JW (1999) Axonal atrophy: the retraction reaction. Curr Opin Neurobiol 9:364-370.

Bernstein ML, Parsadanian AS, Keller-Peck CR, Snider WD, Lichtman JW (1998) Axotomy induces both GDNF sensitivity in regenerating axons and GDNF expression in Schwann cells. Soc Neurosci Abstr 24:1034

Brown MC, Jansen JKS, VanEssen D (1976) Polyneuronal innervation of skeletal muscle in new-born rats and its elimination during maturation. J Physiol (Lond) 261:387-422.

Cabelli RJ, Hohn A, Shatz CJ (1995) Inhibition of ocular dominance column formation by infusion of NT-4/5 or BDNF. Science 267:1662-1666.

Cabelli RJ, Shelton DL, Segal RA, Shatz CJ (1997) Blockade of endogenous ligands of TrkB inhibits formation of ocular dominance columns. Neuron 19:63-76.

Causing CG, Gloster A, Aloyz R, Bamji SX, Chang E, Fawcett J, Kuchel G, Miller FD (1997) Synaptic innervation density is regulated by neuron-derived BDNF. Neuron 18:257-267.

Cheng T-C, Hanley TA, Mudd J, Merlie JP, Olson EN (1992) Mapping of myogenin transcription during embryogenesis using transgenes linked to the myogenin control region. J Cell Biol 119:1649-1656.

Durbec P, Marcos-Gutierrez CV, Kilkenny C, Grigoriou M, Wartiowaara K, Suvanto P, Smith D, Ponder B, Costantini F, Saarma M, Sariola H, Pachnis V (1996) GDNF signalling through the Ret receptor tyrosine kinase. Nature 381:789-793.

English AW, Schwartz G (1995) Both basic fibroblast growth factor and ciliary neurotrophic factor promote the retention of polyneuronal innervation of developing skeletal muscle fibers. Dev Biol 169:57-64.

Feng G, Mellor RH, Bernstein M, Keller-Peck C, Nguyen QT, Wallace M, Gross J, Nerbonne JM, Lichtman JW, Sanes JR (2000) Imaging neuronal subsets in transgenic mice expressing multiple spectral variants of GFP. Neuron 28:41-51.

Ghosh A, Carnahan J, Greenberg ME (1994) Requirement for BDNF in activity-dependent survival of cortical neurons. Science 263:1618-1623.

Golden JP, Baloh RH, Kotzbauer PT, Lampe PA, Osborne PA, Milbrandt J, Johnson EMJ (1998) Expression of neurturin, GDNF, and their receptors in the adult mouse CNS. J Comp Neurol 398:139-150.

Gonzalez M, Ruggiero FP, Chang Q, Shi YJ, Rich MM, Kraner S, Balice-Gordon RJ (1999) Disruption of Trkb-mediated signaling induces disassembly of postsynaptic receptor clusters at neuromuscular junctions. Neuron 24:567-583. 
Henderson CE, Phillips HS, Pollock RA, Davies AM, Lemeulle C, Armanini M, Simpson LC, Moffet B, Vandlen RA, Koliatsos VE, Rosenthal A (1994) GDNF: A potent survival factor for motoneurons present in peripheral nerve and muscle. Science 266:1062-1064.

Henderson CE, Yamamoto Y, Livet J, Arce V, Garces A, deLapeyriere O (1998) Role of neurotrophic factors in motoneuron development. J Physiol (Paris) 92:279-281.

Ho TW, Bristol LA, Coccia C, Li Y, Milbrandt J, Johnson E, Jin L, Bar-Peled O, Griffin JW, Rothstein JD (2000) TGFbeta trophic factors differentially modulate motor axon outgrowth and protection from excitotoxicity. Exp Neurol 161:664-675.

Jing S, Wen D, Yu Y, Holst PL, Luo Y, Fang M, Tamir R, Antonio L, Hu Z, Cupples R, Louis J-C, Hu S, Altrock BW, Fox GM (1996) GDNFinduced activation of the Ret protein tyrosine kinase is mediated by GDNFR- $\alpha$, a novel receptor for GDNF. Cell 85:1113-1124.

Jordan CL (1996) Ciliary neurotrophic factor may act in target musculature to regulate developmental synapse elimination. Dev Neurosci 18:185-198.

Kang H, Schuman EM (2000) Intracellular $\mathrm{Ca}(2+)$ signaling is required for neurotrophin-induced potentiation in the adult rat hippocampus. Neurosci Lett 282:141-144.

Klein RD, Sherman D, Ho W-H, Stone D, Bennett GL, Moffat B, Vandlan R, Simmons L, Gu Q, Hongo J-A, Devaux B, Poulsen K, Armanini M, Nozaki C, Asai N, Goddard A, Phillips H, Henderson CE, Takahashi M, Rosenthal A (1997) A GPI-linked protein that interacts with Ret to form a candidate neurturin receptor. Nature 387:717-721.

Kotzbauer PT, Lampe PA, Heuckeroth RO, Golden JP, Creedon DJ, Johnson EMJ, Milbrandt J (1996) Neurturin, a relative of glial-cellline-derived neurotrophic factor. Nature 384:467-470.

Kwon YW, Gurney ME (1996) Brain-derived neurotrophic factor transiently stabilizes silent synapses on developing neuromuscular junctions. J Neurobiol 29:503-516.

Kwon YW, Abbondanzo SJ, Stewart CL, Gurney ME (1995) Leukemia inhibitory factor influences the timing of programmed synapse withdrawal from neonatal muscles. J Neurobiol 28:35-50.

Li L, Wu W, Lin L-FH, Lei M, Oppenheim RW, Houenol LJ (1995) Rescue of adult mouse motoneurons from injury-induced cell death by glial cell line-derived neurotrophic factor. Proc Natl Acad Sci USA 92:9771-9775

Li YX, Zhang Y, Lester HA, Schuman EM, Davidson N (1998) Enhancement of neurotransmitter release induced by brain-derived neurotrophic factor in hippocampal neurons. J Neurosci 18:10231-10240.

Lichtman JW, Colman H (2000) Synapse elimination and indelible memory. Neuron 25:269-278.

Marques MJ, Conchello J-A, Lichtman JW (2000) From plaque to pretzel: fold formation and acetylcholine receptor loss at the developing neuromuscular junction. J Neurosci 20:3663-3675.

McAllister AK, Lo DC, Katz LC (1995) Neurotrophins regulate dendritic growth in developing visual cortex. Neuron 15:791-803.

McAllister AK, Katz LC, Lo DC (1997) Opposing roles for endogenous BDNF and NT-3 in regulating cortical dendritic growth. Neuron 18:767-778.

Milbrandt J, deSauvage FJ, Fahrner TJ, Baloh RH, Leitner ML, Tansey MG, Lampe PA, Heuckeroth RO, Kotzbauer PT, Simburger KS, Golden JP, Davies JA, Vejsada R, Kato AC, Hynes M, Sherman D, Nishimura M, Wang L-C, Vandlen R, Moffat B, Klein RD, Poulsen K, Gray C, Garces A, Henderson CE, Phillips HS, Johnson EMJ (1998)
Persephin, a novel neurotrophic factor related to GDNF and neurturin. Neuron 20:245-253.

Naveilhan P, ElShamy WM, Ernfors P (1997) Differential regulation of mRNAs for GDNF and its receptors Ret and GDNFR $\alpha$ after sciatic nerve lesion in the mouse. Eur J Neurosci 9:1450-1460.

Nguyen QT, Parsadanian AS, Snider WD, Lichtman JW (1998) Hyperinnervation of neuromuscular junctions caused by GDNF overexpression in muscle. Science 279:1725-1729.

Nosrat CE, Tomac A, Lindqvist E, Lindskog S, Humpel C, Strömberg I, Ebendal T, Hoffer BJ, Olson L (1996) Cellular expression of GDNF mRNA suggests multiple functions inside and outside the nervous system. Cell Tissue Res 286:191-207.

Oppenheim RW, Houenou LJ, Johnson JE, Lin L-FH, Li. L, Lo AC, Newsome AL, Prevette DM, Wang S (1995) Developing motor neurons rescued from programmed and axotomy-induced cell death by GDNF. Nature 373:344-346.

Oppenheim RW, Houenou LJ, Parsadanian AS, Prevetter D, Snider WD, Shen L (2000) Glial cell line-derived neurotrophic factor and developing mammalian motoneurons: regulation of programmed cell death among motoneuron subtypes. J Neurosci 20:5001-5011.

Pachnis V, Mankoo B, Costantini F (1993) Expression of the c-ret protooncogene during mouse embryogenesis. Development 119:1005-1017.

Schuman EM (1999) Neurotrophin regulation of synaptic transmission. Curr Opin Neurobiol 9:105-109.

Smith DS, Skene JH (1997) A transcription-dependent switch controls competence of adult neurons for distinct modes of axon growth. J Neurosci 17:646-658.

Snider WD, Lichtman JW (1996) Are neurotrophins synaptotrophins? Mol Cell Neurosci 7:433-442.

Son YJ, Thompson WJ (1995a) Schwann cell processes guide regeneration of peripheral axons. Neuron 14:125-132.

Son Y-J, Thompson WJ (1995b) Nerve sprouting is induced and guided by processes extended by Schwann cells. Neuron 14:133-141.

Treanor JJS, Goodman L, deSauvage F, Stone DM, Poulsen KT, Beck CD, Gray C, Armanini MP, Pollock RA, Hefti F, Phillips HS, Goddard A, Moore MW, Buj-Bello A, Davies AM, Asai N, Takahashi M, Vandlen R, Henderson CE, Rosenthal A (1996) Characterization of a multicomponent receptor for GDNF. Nature 382:80-83.

Trupp M, Rydén M, Jörnvall H, Funakoshi H, Timmusk T, Arenas E, Ibáñez CF (1995) Peripheral expression and biological activities of GDNF, a new neurotrophic factor for avian and mammalian peripheral neurons. J Cell Biol 130:137-148.

Trupp M, Arenas E, Fainzilber M, Nilsson A-S, Sieber B-A, Grigoriou M, Kilkenny C, Salazar-Grueso E, Pachnis V, Arumäe U, Sariola H Saarma M, Ibáñez CF (1996) Functional receptor for GDNF encoded by the c-ret proto-oncogene. Nature 381:785-789.

Trupp M, Belluardo N, Funakoshi H, Ibáñez CF (1997) Complementary and overlapping expression of glial cell line-derived neurotrophic factor (GDNF), c-ret proto-oncogene, and GDNF receptor- $\alpha$ indicates multiple mechanisms of trophic actions in the adult rat CNS. J Neurosci 17:3554-3567.

Tsuzuki T, Takahashi M, Asai N, Iwashita T, Matsuyama M, Asai J (1995) Spatial and temporal expression of the ret proto-oncogene product in embryonic, infant and adult rat tissues. Oncogene 10:191-198.

Yan Q, Matheson C, Lopez OT (1995) In vivo neurotrophic effects of GDNF on neonatal and adult facial motor neurons. Nature 373:341344. 